From the Department of Pharmacology and Toxicology, Norwegian College of Veterinary Medicine, Oslo and Norwegian Defence Research Establishment, Division for Environmental Toxicology, Kjeller, Norway.

\title{
Cholinesterase Activities in Uterus of Normal and Fenchlorphos Treated Blue Foxes (Alopex Lagopus) during Various Reproductive States
}

\author{
By Gunnar N. Berge, Sigrun H. Sterri \& Nils E. Søli
}

\begin{abstract}
Berge G. N., S. H. Sterri and N. E. Seli: Cholinesterase activities in uterus of normal and fenchlorphos treated blue foxes (Alopex lagopus) during various reproductive states. Acta vet. scand. 1988, 29, 117-123. - The uterine acetylcholinesterase and total cholinesterase (acetylcholinesterase plus butyrylcholinesterase) activities in normal and fenchlorphos treated blue fox vixens were determined during various reproductive states.

$\mathrm{AChE}$ and Total-ChE of non-medicated vixens in oestrus were about one half of those in anoestrus. In pregnant uteri (luteal phase) the activities were $25 \%$ and $30 \%$ compared to anoestrus.

In vixens given $100 \mathrm{mg} / \mathrm{kg}$ fenchlorphos for 3 weeks during anoestrus, the remaining activity of $\mathrm{AChE}$ in uterus were in average $37 \%$. Pregnant and non-pregnant vixens in the luteal phase medicated prior to mating and during time of implantation, displayed $\mathrm{AChE}$ activities which were only moderabely reduced (remaining activities $83 \%$ and $72 \%$ compared to medicated animals in anoestrus: remaining activity $37 \%$ ).

Plasma ChE-activity increased during pregnancy in the controls while enzyme activity was strongly reduced in animals given $100 \mathrm{mg} / \mathrm{kg}$ fenchlorphos daily through the whole pregnancy.

It was concluded that the previous reported embryotoxic effect of fenchlorphos in the blue fox did not seem to be directed towards the moderate inhibition of the uterine cholinesterases.
\end{abstract}

organophosphorus compound; enzymes; breeding season; smooth muscle; vixens.

\section{Introduction}

In a clinical investigation, Berge (1981) found that fenchlorphos was effective against sarcoptic mange in blue foxes at a dose of $100 \mathrm{mg} / \mathrm{kg}$ daily for 3-5 weeks. Søli et al. (1977) examined the effect of systemically administered fenchlorphos on the blood cholinesterase. It was concluded that fenchlorphos administered in doses recommended to dogs, $100 \mathrm{mg} / \mathrm{kg}$ daily for 3 weeks, was well tolerated by healthy foxes.
Berge \& Nafstad (1983) found, however, that the compound was embryotoxic and teratogenic when given orally in therapeutic doses to pregnant foxes. The mean number of living whelps at term was only 1.2 per vixen versus 9.5 in the control groups. Since very little information was available concerning normal cholinesterase activities in the uterus during the breeding season, we decided to examine normal activities during various reproductive states. Particular atten- 
tion was focused on the effects of fenchlorphos upon the cholinesterases in the uterus in order to examine whether the previously reported low number of whelps from medicated vixens could be connected with cholinesterase inhibition.

\section{Materials and methods \\ Chemical}

The organophosphorus insecticide fenchlorphos, 0,0-dimethyl-0-(2,4,5-trichlorophenyl) phosphorothioate was used in the form of Ectoral ${ }^{\circledR}$ tablets $(250 \mathrm{mg})$, PitmanMoore, Inc., USA.

\section{Animals and housing}

The blue foxes used were 1-year old vixens. All the animals were housed individually outdoors at the Research Farm for Furbearing Animals, Heggedal. They were given a standard Norwegian wet feed and water ad libitum.

\section{Animal experiments}

Experiment I: Five vixens in anoestrus and 5 vixens in induced oestrus were used for the experiment. Oestrus was induced by intramuscular injection of 500 IU serum gonadotropin (Antex ${ }^{2}$ ) daily for 3 days, and of $500 \mathrm{IU}$ serum gonadotropin (Antex) $+5 \mathrm{mg}$ diethylstilboestrol i.m. on the fourth day, and $500 \mathrm{IU}$ serum gonadotropin (Antex) on the fifth day. Three days later $10 \mathrm{mg}$ diethylstilboestrol was injected. By this procedure oestrus appeared the day after the last treatment.

All the vixens were ovariohysterectomized. The operation was performed through a midline incision under xylazine (Rompun ${ }^{\circledR}$ ) sedation. The uterine samples were collected from the middle of the uterine horns.

Experiment II: The experiment was conducted with 10 female blue foxes in anoe- strus divided in 2 groups. The non-medicated group comprised 5 vixens (the same animals as in Experiment I). The 5 vixens in the medicated group were given $100 \mathrm{mg}$ fenchlorphos/kg orally daily for 3 weeks. At the end of the experiment the animals were ovariohysterectomized and the samples were collected as in Experiment I. Blood samples for cholinesterase examination were taken from all animals prior to ovariohysterectomy.

Experiment III: Ten female blue foxes were employed in the experiment. All the vixens were mated twice, generally on the 2 nd and 4th day of sexual receptivity. The last day of mating was considered as day 0 of gestation. Four animals were orally administered $100 \mathrm{mg}$ fenchlorphos/ $\mathrm{kg}$ daily from approximately 10 days before oestrus until day 21 of gestation. The vixens were ovariohysterectomized 2 days later. The same procedure was performed in 6 nonmedicated animals. Following the result of the mating, the vixens were divided in 2 groups, pregnant and nonpregnant animals, respectively. In all the vixens, samples of different parts of uterus were collected for analysis.

Experiment IV: The experiment was conducted with 9 pregnant animals. Blood samples for butyrylcholinesterase activity determinations were taken at selected intervals during pregnancy and for a short time after delivery. Four vixens served as controls while 5 were given $100 \mathrm{mg}$ fenchlorphos/ $\mathrm{kg}$ orally through the whole pregnancy.

\section{Preparation of the samples}

Uterine samples. The uterus was removed and cooled on ice immediately and then stored in plastic bags at $-18^{\circ} \mathrm{C}$. Samples of intact uterus wall consisting of both uterine myometrium and mucosa were taken after 
thawing of the intact uterus in room temperature. The tissue preparations were kept cold until analysed. For the acetylcholinesterase analysis a $8 \%(w / v)$ homogenate was prepared in $20 \mathrm{mmol} / 1$ phosphate buffer $\mathrm{pH}$ 7.4 containing $2 \%$ Triton $X-100$. For the total cholinesterase analysis, the homogenate was diluted with 3 volumes of the same buffer. Preliminary investigations showed that centrifuged homogenate revealed the same enzyme activity as non-centrifuged samples. For convenience all samples were therefore centrifuged before analysis.

Blood samples. Heparinized blood was centrifuged and plasma removed. The erythrocytes were then resuspended in $0.9 \%$ $\mathrm{NaC1}$ to the original volume and $0.2 \mathrm{ml}$ of the mixture was centrifuged. The erythrocytes were washed once more with $0.9 \%$ $\mathrm{NaC1}$. Then the erythrocytes were dissolved in $0.5 \mathrm{ml} 0.1 \%$ Triton $\mathrm{X}-100$, and diluted with $3 \mathrm{ml}$ of $20 \mathrm{mmol} / \mathrm{l}$ sodium phosphate buffer $\mathrm{pH} 7.4$.

\section{Determination of cholinesterases}

The acetylcholinesterase activity was measured by the radiochemical method of Sterri \& Fonnum (1978). Total cholinesterase activity (acetylcholinesterase + butyrylcholinesterase) was determined by the same method, omitting ethopropazine in the assay mixture. The standard deviation of 10 parallel measurements was less than $3 \%$.

\section{Results}

The results from Experiment I (Table 1) showed that both uterine AChE and Total-ChE activities in oestrus of non-medicated blue fox vixens were about one half of those in anoestrus (46\% and 55\%, respectively).

In vixens given $100 \mathrm{mg} / \mathrm{kg}$ fenchlorphos daily for 3 weeks during anoestrus (Experiment II), the remaining activities of $\mathrm{AChE}$ in ute-
Table 1. Uterine acetylcholinesterase (AChE) and total cholinesterase (Total-ChE) activities ( $\mathrm{nmol} / \mathrm{h} / \mathrm{mg}$ tissue) in non-medicated anoestrus and oestrus blue fox vixens (mean $\pm \mathrm{SD}$ ). Experiment $\mathrm{I}$.

\begin{tabular}{lcc}
\hline & AChE & Total-ChE \\
\hline $\begin{array}{l}\text { Anoestrus } \\
(\mathrm{n}=5)\end{array}$ & $24 \pm 5$ & $191 \pm 29$ \\
$\begin{array}{l}\text { Oestrus } \\
(\mathrm{n}=5\end{array}$ & $11 \pm 3$ & $106 \pm 24$ \\
\hline
\end{tabular}

rus and erythrocytes were 37 and $31 \%$, respectively (Table 2 ).

In Experiment III pregnancy was recorded in 2 of 4 medicated and in 3 of 6 control animals at day 23 of gestation. Implantation sites were detected in the non-pregnant control animals but not in the medicated group. There was no obvious difference between $\mathrm{AChE}$ activities in the body of the uterus (in average $12 \mathrm{nmol} / \mathrm{h} / \mathrm{mg}$ tissue) and activities in uterine horns (in average $11 \mathrm{nmol} / \mathrm{h} / \mathrm{mg}$ tissue) of non-pregnant animals in the luteal phase. Similar results were observed in uterus of pregnant animals ( 7 and $6 \mathrm{nmol} / \mathrm{h} / \mathrm{mg}$ tissue, respectively). Samples of the uterine horns taken between 2 fetuses indicated similar activities (6 $\mathrm{nmol} / \mathrm{h} / \mathrm{mg}$ tissue). The AChE activities in the cervix, however, were higher (16 nmol/h/mg tissue) than the activities measured in other parts of the uterus of pregnant vixens. In pregnant uteri the

Table 2. Acetylcholinesterase (AChE) activities ( $\mathrm{nmol} / \mathrm{h} / \mathrm{mg}$ tissue) in uterus and erythrocytes of anoestrus blue fox vixens given oral doses of $100 \mathrm{mg}$ fenchlorphos $/ \mathrm{kg}$ daily for 3 weeks (mean \pm SD). Experiment II.

\begin{tabular}{lcc}
\hline & Uterus & Erythrocytes \\
\hline $\begin{array}{l}\text { Controls } \\
(\mathrm{n}=5)\end{array}$ & $24 \pm 5$ & $58 \pm 4$ \\
$\begin{array}{l}\text { Medicated } \\
(\mathrm{n}=5)\end{array}$ & $\begin{array}{c}9 \pm 2 \\
(37 \%)\end{array}$ & $\begin{array}{c}19 \pm 3 \\
(31 \%)\end{array}$ \\
\hline
\end{tabular}


AChE and Total-ChE activities were about $25 \%$ and $30 \%$ of those in anoestrus.

The uterine AChE in the luteal phase were lower in pregnant than in non-pregnant animals (Table 3), while no essential differences were observed in the Total-ChE activities. It is noteworthy that the AChE activities in both pregnant and non-pregnant medicated animals in the luteal phase were only moderately reduced compared to medicated animals in anoestrus.

In Experiment IV plasma butyrylcholinesterase activity increased during pregnancy in the controls, while enzyme activity was almost maximally reduced in the medicated vixens (6-17\% of the activities at mating). The inhibition was extensive during the whole period of pregnancy (Fig. 1).

\section{Discussion}

The present study have demonstrated variations in the activity of cholinesterases in uterus of blue foxes dependent on the reproductive state. The inhibition of the cholinesterases following administrations of fenchlorphos in therapeutic doses was extensive in



DAYS AFTER MATING

Figure 1. Variations in butyrylcholinesterase activity in blue fox vixens given fenchlorphos orally at a dose of $100 \mathrm{mg} / \mathrm{kg}$ daily throughout pregnancy. Experiment IV. 
Table 3. Acetylcholinesterase (AChE) and total cholinesterase (Total$\mathrm{ChE}$ ) activities ( $\mathrm{nmol} / \mathrm{h} / \mathrm{mg}$ tissue) in uterus of non-pregnant and pregnant blue fox vixens in luteal phase given oral doses of $100 \mathrm{mg}$ fenchlorphos $/ \mathrm{kg}$ daily from day 10 before mating to day 21 of gestation. The figures in parenteses are enzym activities in percent of the average enzyme activities of the controls. Experiment III.

\begin{tabular}{lccccc}
\hline & \multicolumn{2}{c}{ AChE } & & \multicolumn{2}{c}{ Total-ChE } \\
\cline { 2 - 3 } \cline { 6 - 7 } & $\begin{array}{c}\text { Controls } \\
(\mathrm{n}=3)\end{array}$ & $\begin{array}{c}\text { Medicated } \\
(\mathrm{n}=2)\end{array}$ & & $\begin{array}{c}\text { Controls } \\
(\mathrm{n}=3)\end{array}$ & $\begin{array}{c}\text { Medicated } \\
(\mathrm{n}=2)\end{array}$ \\
\hline Non-pregnant & 11 & $8(72 \%)$ & & 58 & $42(72 \%)$ \\
Pregnant & $6(55 \%)$ & $5(83 \%)$ & & 61 & $33(54 \%)$ \\
\hline
\end{tabular}

non-pregnant animals, but only moderate in pregnant ones.

In contrast to the non-pregnant controls, no formation of implantation sites were detected in uterus of mated medicated non-pregnant vixens. When given prior to mating and during time of implantation (i.e. about the same period as in the present study) Berge \& Nafstad (1983) suggested that fenchlorphos might interfere with the process of fertilization.

Silver (1978), who studied the cholinesterase activities in the ovaries, found species variations in the distribution as well as variations in enzyme activity of different reproductive states. The present investigation in the blue fox have indicated significant differences in $\mathrm{AChE}$ activities between uterus in anoestrus (24 $\mathrm{nmol} / \mathrm{h} / \mathrm{mg}$ tissue) and luteal phase (6 $\mathrm{nmol} / \mathrm{h} / \mathrm{mg}$ tissue). In addition we observed variations in the AChE activities of different parts of the uterus as reflected by higher activities in the cervix than in the uterine horn and body. According to studies of human uterus Coupland $(1962,1969)$ observed a rich supply of acetylcholinesterase positive nerves to the cervical mucosa and similar but sparser supply to the mucosa of the body of the uterus.

In spite of a longer period of medication in the pregnant animals (luteal phase), uterine acetylcholinesterase activity was only moderately reduced compared to the animals in anoestrus. A similar tendency of bloodAChE between pregnant and non-pregnant animals was observed in rabbits (Nafstad et al. 1983). We can therefore not exclude the possibility that these findings may be due to an increased inactivation of fenchlorphos in pregnant animals.

The innervation of uterus has been the subject of many comprehensive studies and surveys. While rabbit, cat and human uterine muscle seems to be innervated almost exclusively from the adrenergic nervous system (Owman \& Sjøberg 1966, Rosengren \& Sjøberg 1967, Owman et al. 1967), rat uterine muscle is innervated mainly by cholinergic nerves (Kanerva et al. 1972). By analogy with other visceral structures it has been suggested that $\mathrm{AChE}$ associated with nerves in the uterus will be concerned with mechanisms controlling smooth muscle and that cholinesterase activity in the uterine nerves may be influenced by sex hormones (Silver 1974, 1978).

In foxes, however, there was no evidence that profiles and plasma concentrations of oestradiol-17ß, progesterone or luteinizing hormon were influenced by fenchlorphos, when medicated prior to mating and during early pregnancy (Berge et al. 1983). Accor- 
ding to these results there is no direct indication that the embryotoxic and teratogenic effects of fenchlorphos was associated with hormonal disturbances.

The inhibition of plasma butyrylcholinesterase $(\mathrm{BuChE})$ was extensive in the medicated vixens, especially because the activity of $\mathrm{Bu}$ ChE increased during pregnancy. A tendency toward increment in BuChE activity from the start to the end of gestation, was also observed in the rabbit (Nafstad et al. 1983). However, the pattern of the enzyme in these species is in contrast to the situation in women where a rapid fall takes place during the first trimester (Levine \& Hoyt 1949, Howard et al. 1978, Kuhnert \& Kuhnert 1979, Evans \& Wroe 1980, Ravindran et al. 1982).

Suggestions that non-neuronal cholinesterases in the uterus are related to secretory functions has been postulated (Silver 1978). Whether an alteration in the uterine secretory functions caused by fenchlorphos could influence the normal embryonic development remains to be clarified.

Since the significance of the cholinesterases in uterus is rather obscure, we can not exclude the possibility that small variations in the activities may influence normal development. However, minor reduction in cholinesterase activities are usually not associated with toxicological alteration of permanent nature.

\section{References}

Berge $G N$ : Behandling av skabb hos blårev (Treatment of mange in the blue fox). Norsk Vet.-T. 1981, 93, 413-419.

Berge G N, Nafstad I: Teratogenicity and embryotoxicity of orally administered fenchlorphos in blue foxes. Acta vet. scand. 1983, 24, 99-112.

Berge GN, Mondain-Monval M, Smith A, Möller O: Ovarian and testicular function in the blue fox (Alopex lagopus) after oral administration of fenchlorphos during the breeding season. Acta vet. scand. 1983, 24, 200-210.

Coupland $R E$ : Histochemical observations on the distribution of cholinesterase in the human uterus. J. Obstet. Gynaec. Brit. Emp. 1962, 69, 1041-1043.

Coupland $R E$ : The distribution of cholinergic and other nerve fibers in the human uterus. Postgrad. Med.J. 1969, 45, 78-79.

Evans $R$ J, Wroe J M: Plasmacholinesterase changes during pregnancy. Anasthesia 1980, 35, 651-654.

Howard JK, Jean East N, Chaney J L: Plasma cholinesterase activity in early pregnancy. Arch. environ. Health 1978, 33, 277-279.

Kanerva L, Mustonen T, Teräväinen $H$ : Histochemical studies of uterine innervation after neurectomies. Acta physiol. scand. 1972, 86, 359-365.

Kuhnert B R, Kuhnert $P$ M: Letter to the editor. Arch. environ. Health 1979, 34, 285.

Levine $M G$, Hoyt $R E$ : Serum cholinesterases in some pathological conditions. Proc. Soc. exp. Biol. Med. 1949, 70, 50-53.

Nafstad I, Berge G N, Sannes E, Lyngset A: Teratogenic effects of the organophosphorus compound fenchlorphos in rabbits. Acta vet. scand. 1983, 24, 295-304.

Owman C, Sjeberg N-O: Adrenergic nerves in the female genital tract of the rabbit with remarks on cholinesterasecontaining structures. Z. Zellforsch. Abt. Histochem. 1966, 74, 182-197.

Owman C, Rosengren E, Sjøberg N-O: Adrenergic innervation of the human female reproductive organs: A histochemical and chemical investigation. J. Obstet. Gynaec. 1967, 30, 763-773.

Ravindran R S, Cummins D F, Pantazis $K L$, Strausburg $B J$, Baenziger $J C$ : Unusual aspects of low levels of pseudocholinesterase in a pregnant patient. Anesth. Analg. 1982, 61, 953-955.

Rosengren E, Sjøberg $\mathrm{N}-\mathrm{O}$ : The adrenergic nerve supply to the female reproductive tract of the cat. Amer. J. Anat. 1967, 121, 271-284.

Silver A: The Biology of Cholinesterases. Amsterdam: North Holland Publishing Co. 1974, 393396.

Silver A: Species variations in the distribution of cholinesterases in the ovary of the plains viscacha, cat, ferret, rabbit, rat, guinea-pig and roe deer. Histochem. J. 1978, 10, 79-102. 
Sterri S H, Fonnum F: Isolation of organic anions by extraction with liquid anion exchangers and its application to micromethods for acetylcholinesterase and 4-aminobutyrate aminotransferase. Eur. J. Biochem. 1978, 91, 215-222.

Søli NE, Andersen R A, Utne Skaare J, Mikalsen A: The effect of 0,0-dimethyl-0-(2,4,5-trichlorophenyl) phosphorothioate (fenchlorphos) on cholinesterases in the blue fox (Alopex lagopus). Acta vet. scand. 1977, 18, 408-415.

\section{Sammendrag}

Kolinesteraseaktiviteter $i$ uterus under seksualsyklus og drektighet hos normale og fenklorfos-behandlede blàrever.

Acetylkolinesterase og total kolinesterase (acetylkolinesterase pluss butyrylkolinesterase) aktiviteter $\mathbf{i}$ uterus hos normale og fenklorfos-behandlede blårever ble undersøkt under seksualsyklus og drektighet.
Resultatene viste at kolinesteraseaktivitetene varierte i de ulike reproduksjonsstadiene. Aktivitetene var høyest $i$ anøstrus og lavest $i$ lutealfasen (drektige dyr).

Hos blårevtisper som ble administrert $100 \mathrm{mg} / \mathrm{kg}$ fenklorfos daglig i 3 uker av anøstrus, var aktiviteten av AChE i uterus $37 \%$. Tisper, administrert fra 10. dag før parring til 21. dag etter, viste imidlertid både hos drektige og tomme dyr i lutealfasen kun en moderat hemning av AChE sammenlignet med behandlede dyr $i$ anøstrus.

Plasma kolinesteraseaktiviteter økte under drektigheten på kontrolldyrene, mens enzymaktivitetene falt tydelig hos dyr gitt $100 \mathrm{mg}$ fenklorfos/ $\mathrm{kg}$ daglig gjennom hele drektighetsperioden.

Det konkluderes med at det er liten sannsynlighet for at den tidligere rapporterte embryotoksiske effekten av fenklorfos kan settes i forbindelse med den moderate hemningen av kolinesterasene $i$ uterus.

(Received September 28, 1987).

Reprints may be requested from: N. E. Søli, Department of Pharmacology and Toxicology, Norwegian College of Veterinary Medicine, P. O. Box 8146 Dep., Oslo 1, Norway. 
